\title{
Kirjallisuus, digitaalisuus, ympäristöllisyys
}

Erilaisia digiloikkia vauhdilla ottava yhteiskunta on usein herättänyt huolta niin kirjallisuudentutkijoissa kuin humanisteissa laajemminkin: onko kirjallisuudella ja muulla "hitaalla" taiteella ja tekemisellä enää paikkaa tai tilausta?

Tämä teemanumero kartoittaa kirjallisuuden, sen tutkimuksen ja digitaalisten teknologioiden läpitunkevan ympäristöllisyyden suhteita. Kirjallisuudentutkimus on otollinen ala digitalisoituvan kulttuurin ja yhteiskunnan analyysille, sillä se on lähtökohtaisesti monitieteinen tutkimusala, joka käsittelee tekstejä, niiden tuottamista ja konteksteja monista eri näkökulmista. Sen piiriin ovat aina mahtuneet niin erilaiset mediumit, toimijat kuin materiaalisuudetkin. Tässä teemanumerossa julkaistut tekstit tunnistavat erilaisia kulttuurin digitalisoitumiseen liittyviä kysymyksiä ja näyttävät osaltaan esimerkkiä näiden suhteisuuksien käsittelyyn. Ne osoittavat vastaansanomattomasti, että vanhan ja uuden, tai analogisen ja digitaalisen välisistä dikotomioista on hedelmällisempää siirtyä kohti näiden rinnakkaiseloa ja lomittumista.

Numeron avaava artikkelimme (jonka toimittamisesta kiitos kuuluu Lottamari Kähköselle ja Riitta Jytilälle) jäsentää digitaalisen ympäristöllisyyden merkitystä kirjallisuudentutkimukselle. Tarkoitamme ympäristöllisyydellä digitaalisen teknologian luomia olosuhteita, jotka ympäröivät ja muovaavat erilaisia kirjoittamisen ja lukemisen tilanteita. Tarkastelemme tästä lähtökohdasta teknologian, kirjallisuuden ja ihmiskäyttäjän toimijuuden suhteita. Näin artikkelimme luo ja avaa teoreettista pohjaa erilaisille kirjallisuuden ja digitaalisuuden lomittumisille, joita seuraavat neljä artikkelia kartoittavat tarkkarajaisempien tutkimuskohteiden kautta.

Matti Kangaskosken artikkeli tarkentaa digitaalisiin kulttuurikäyttöliittymiin - kuten striimauspalveluihin, verkkokauppoihin ja sosiaaliseen mediaan merkittävänä osana tapaamme kohdata kulttuurituotteita ja ajatuksia. Tapausesimerkkinään Instagram-runous Kangaskoski tarkastelee käyttöliittymien piilevää normatiivisuutta ja niiden tuottamaa kulttuurista poetiikkaa, joka syntyy sekä kulttuurikäyttöliittymien logiikan että tarjoumien seurauksena.

Helena Mäntyniemen artikkeli tarkastelee internetissä julkaistua, faniyhteisön kollektiivisesti tuottamaa Harry Potter -fanifiktiota yhteiskunnallisen keskustelun alustana yhteistekijyyden poetiikan kautta. Mäntyniemi keskittyy erityisesti intersektionaalisen feminismin periaatteiden ilmenemiseen paitsi teksti-implisiittisessä poetiikassa eli muun muassa fanifiktiotekstien rakenteissa, keinoissa ja lajeissa, myös niin sanotussa julkilausutussa poetiikassa eli kirjoittajaryhmien kirjoitusohjeissa ja keskinäisissä keskusteluissa ilmi tulevissa periaatteissa. 
Juha-Pekka Kilpiön artikkeli käsittelee Mika Taanilan ja Harry Salmenniemen ilman kameraa tehtyä kokeellista elokuvaa Mannerlaatta (2016) sekä vertailee sitä ja korealais-amerikkalaisen Young-Hae Chang Heavy Industries -taiteilijaparin tekstuaalisia elokuvia. Kilpiö analysoi media-arkeologian keinoin sekä analogisen ja digitaalisen että kirjallisen ja elokuvallisen risteyskohdassa liikkuvien teosten mediaalisia ominaispiirteitä ja erittelee Mannerlaatassa risteävien, eri aikakausia edustavien teknologioiden rinnakkaiseloa.

Anna Kajanderin artikkeli osallistuu keskusteluun lukemisen muutoksesta, sähköisistä kirjamuodoista sekä painetun kirjan asemasta ja tulevaisuudesta. Suomalaisen Kirjallisuuden Seuran vuonna 2014 keräämän Elämää lukijana -kirjoituskeruuaineiston pohjalta Kajander selvittää materiaalisen kulttuurin tutkimuksen näkökulmasta sitä, millaiset kokemukset voivat vaikuttaa lukijoiden käsityksiin erilaisista kirjamuodoista ja lukemisen tavoista, ja keskittyy analyysissaan etenkin omaelämäkerralliseen materiaalisuuteen ja digitaaliseen materiaalisuuteen.

Virpi Vairinen avaa teemanumeron kahdesta puheenvuorosta ensimmäisessä suomalaisen elektronisen kirjallisuuden monipuolista kenttää Nokturno. $\mathrm{fi}$-julkaisualustan näkökulmasta. Vairinen tuo esiin elektronisen kirjallisuuden luonteen usein kansainvälisissä yhteisöissä syntyvänä ja kehittyvänä post-internet-ajan taiteena. Toisessa puheenvuorossa Maria Mäkelän johtama Kertomuksen vaarat -tutkimusryhmä reflektoi vuosina 2017-2020 toiminutta samannimistä kirjallisuudentutkimuksen hanketta, joka hyödynsi digitaalisia ympäristöjä, pääasiassa sosiaalista mediaa, sekä aineistonkeruussa että tiedeviestinnässä. Ryhmä pohtii etenkin niitä eettisiä ja epistemologisia haasteita, jotka liittyvät tutkimushankkeen aktiiviseen läsnäoloon sosiaalisessa mediassa, ja jotka ovat samalla sukua heidän kritisoimalleen "tarinataloudelle".

Numeron kolme kirja-arviota esittelevät kukin kiinnostavaa nykytutkimusta, joka avaa uusia näkökulmia digitaalisen teknologian ympäristöllisyyden eri puoliin. Samalla tekstit pohtivat näiden tutkimusten mahdollista antia tulevalle kirjallisuudentutkimukselle. Kaisa Kortekallio arvioi N. Katherine Haylesin teoksen Unthought: The Power of the Cognitive Nonconscious (2017), Esko Suoranta Shoshana Zuboffin kirjan The Age of Surveillance Capitalism: The Fight for a Human Future at the New Frontier of Power (2019) ja Juha Raipola Sy Taffelin teoksen Digital Media Ecologies: Entanglements of Content, Code and Hardware (2019). On myös paikallaan huomioida, että paljon kiinnostavaa ja olennaista on tilan rajallisuuden vuoksi jäänyt myös tämän teemanumeron ulkopuolelle. Tällaisia aiheita ovat esimerkiksi big datan ja digitaalisten tutkimusmenetelmien ja -välineiden käyttö kirjallisuudentutkimuksessa, digitaalinen geneettinen kritiikki ja "perinteisen" digitaalisen kirjallisuuden tutkimus.

Edellisen numeron pääkirjoituksessa lehden toimittajat totesivat Suomessa tehtävän kirjallisuudentutkimuksen osallistuvan kunnianhimoisesti eri tieteenalojen keskusteluihin ja tutkimuksen kehittämiseen. Yhdymme tähän huomioon, ja sen hengessä ehdotamme myös kysymystä kirjallisuuden ja sen 
tutkimuksen paikasta ja tilauksesta digitaalisen ympäristöllisyyden ajassa muotoiltavaksi hieman toisin. Kysykäämme mieluummin, millainen kirjallisuuden ja sen tutkimuksen suhde digitaaliseen on nyt ja millainen se voisi tulevaisuudessa olla.

Hanna-Riikka Roine \& Laura Piippo 